\title{
Modern Science, Enlightenment, and the Domination of Nature: No Exit?
}

\author{
William Leiss
}

\section{Introduction and Overview}

The disease of reason is that reason was born from man's urge to dominate nature. -Max Horkheimer, Eclipse of Reason (1947)

In the fuller passage from which this extract is taken, Horkheimer locates the origins of the 'collective madness' of modern times in 'in primitive objectification, in the first man's calculating contemplation of the world as prey' (176). Perhaps all one can say in response is, if this diagnosis is correct, there is certainly no cure, so we might as well get on with our lives.

In the early sections of this paper I will first note briefly the argument that the approach taken in Dialectic of Enlightenment and Eclipse of Reason ends in a cul-de-sac. Then I will offer a somewhat different interpretation of the historical dialectic of Enlightenment, arguing that we are still today in the midst of a real, historical conundrumwith potentially fateful consequences— that is playing itself out in contemporary society. Returning once again to the main theme - the relation of modern science to enlightenment and the domination of nature- $\mathrm{I}$ will then try to show how the 'stakes' in this game are now being raised by molecular biology and neurosciences. For it was inevitable that 'human nature' and its most precious attribute, the human mind, would one day become 'objects' to be mastered by the methodology of the natural sciences.

Here is where I will end up: Domination of nature through the progress of the modern natural sciences is the defining historical dialectic of modernity, which has a distinctive internal contradiction that must be addressed and resolved if humanity is to be able to transcend this stage of historical development. I argue against the 'dialectic of enlightenment' because it presupposes what it ought to prove, namely, that there is no exit. On the other hand, this defining historical dialectic is still in the process of development, driven further by its own internal tension. Thus it is still 'open' to qualitatively different final outcomes.

\section{Dialectic of Enlightenment Revised}

In the two main texts from the 1940s, Dialectic of Enlightenment (complete typescript in 1944, first published in 1947) and Eclipse of Reason (1947), three different sets of key concepts appear. One is, of course, 'dialectic of enlightenment,' which may be summed up in the proposition that enlightenment, the enemy of myth, falls victim to its opposite: 'The more completely the machinery of thought subjugates existence, the more blindly is it satisfied with reproducing it. Enlightenment thereby regresses to the mythology it has never been able to escape.'[1] The second is the opposition of objective versus subjective reason: The latter holds that 'reason is a subjective faculty of the mind' and serves the subject's interest in self-preservation; the former holds that 'reason is a principle inherent in reality.'[2] The third is the domination of nature. In seeking to understand how nature works, and thus to control its powers for their benefit, "human beings distance themselves from nature in order to arrange it in such a way 
that it can be mastered.' But the enlarged social apparatus that is required to refine, enlarge, and administer control over nature takes its revenge, for 'the power of the system over human beings increases with every step they take away from the power of nature...'[3] Enlarged, collective domination over nature is matched at every staged by a comparably heightened domination by some people over others.

Although there are differences in the modes of expression used for these three sets of concepts, there are enough similarities, even in the brief quotes given above, to suggest that the three should be regarded as variations on a single theme.[4] That they may represent a single core idea is affirmed in a passage written toward the end of Horkheimer's life:[5]

The immanent logic of social development points to a totally technicized life as its final stage. Man's domination of nature reaches such proportions that scarcity, and thus the necessity of man's dominion over man, disappears. But at the same time, the end is total disillusionment, the extinction of mind insofar as it differs from the tool that is reason.... All this is part of the dialectic of the Enlightenment, the change from truth into unconditioned conformity with meaninglessness, with reality generally.

These sentences evoke nothing so much as Max Weber's 'iron cage' of rationality. Horkheimer's own heading for this passage is: 'On Pessimism.' The idea of a 'final stage' of life that is 'totally technicized' leaves little doubt that this is a path of regressive social development having no exit into a better future (utopia).[6]

This fatalism and explicit pessimism is also summed up well in the sentence quoted at the outset: 'The disease of reason is that reason was born from man's urge to dominate nature.' In locating this dialectic within the 'human condition' as such, in particular, in the very nature of human reason, Horkheimer appeared to pose an insoluble dilemma for social theory. Among other things, this perspective does seem to contradict the underlying basis of critical theory, inasmuch as it is considered to be a variant of the Marxist theory of social change in general, and of modern society in particular, because it places the key issue in human development entirely outside of history and presents it as a constant, essential feature of the species in all of its manifestations over time.

One of the main difficulties created by this overly-expansive concept of instrumental reason lies in the highly indiscriminate use of the word 'domination' in the phrase 'domination of nature.' For this phrase makes no sense when applied to what Horkheimer refers to as the 'primitive' state of Homo sapiens, presumably meaning before the time of early agriculture and settled, as opposed to purely hunter-gatherer, societies. Nor does it make much better sense when applied to the state of premodern civilizations, because in reality there was very little control over nature to speak of.[7] Hobbes's famous description of the condition of humankind in the state of nature, a life 'solitary, poor, nasty, brutish and short,' is - minus the solitary part-a reasonably accurate characterization of the lives of most people in most times to date (excluding the rich, of course), and of many even today. To take just one example, before the age of modern medicine and public health, up to half of all newborns could die in the first year of life; in addition, pregnancy and childbirth represented severe risks of death for women (as is still true today in many places in the world).

Thus there is no sensible way in which 'primitive objectification' can be regarded as the first step on the road to the modern epoch and the form which the domination of nature takes there. This error is compounded in critical theory by 'generalizing' the phenomenon of enlightenment and presenting it as a historical constant, applicable equally to ancient Greece and eighteenth-century Europe. The result is to misrepresent in a fundamental way the true function of the modern enlightenment.

\section{The French Enlightenment}

The opening pages of Dialectic of Enlightenment correctly present Francis Bacon as the original Enlightenment thinker of the modern period, for without a doubt Bacon developed the clearest and most straightforward conception of 'domination over nature' and its relation to the new sciences of nature. In a nutshell, he put the concept in the form of a paradox, which goes like this: Achieving command over nature can only be gained by following nature. [8] One must patiently observe how nature works, taking careful measurements and confirming the accuracy of these observations by systematic experimentation (i.e., replication) — a search that should be driven by the recursive interplay of theory and evidence, not by a purely speculative natural philosophy alone. Patience is required in order to reveal the underlying structure of matter that hides behind the phenomenal appearances of things (Bacon thought 
the alchemists were too impatient, for example). Patience requires a long-range, integrated perspective developed gradually over time by a community of scientists working in different places and corresponding with each other. Bacon also realized that government resources would be needed to subsidize the venture, but he was ahead of his time in this respect and when he died he thought of himself as a failure.

The first — false (because partial or incomplete) — form of the dialectic of modernity was the perceived conflict between the new sciences and the dominant religious world-view. Bacon resolved this apparent conflict quickly, and over time his resolution became widely accepted.[9] He acknowledged the dilemma—namely, that an enlarged 'power over nature' placed into humanity's hands would need to be superintended, somehow—but he dismissed it with a formulaic response. In his book The New Organon (1620) he wrote: 'Only let the human race recover that right over nature which belongs to it by divine bequest, and let power be given it; the exercise thereof will be guided by sound reason and true religion.'[10] He would not live to see the triumph of his program, however. Toward the end of his life he consoled himself by writing a utopian fantasy, The New Atlantis (first published posthumously in 1627), depicting a form of society where an élite scientific research establishment sets its own rules and runs the investigations of nature independently of political authority.

Only towards the end of the eighteenth century, after the French Enlightenment and the French Revolution had swept away the ancient dogmas that stood in the way of the new sciences, could it be said that Bacon's view had finally triumphed. (Bacon was a great hero in the eyes of the Enlightenment thinkers.) And it was only in the works of these eighteenth-century thinkers that the full richness of Bacon's original message became clear-for, remarkably, Bacon, standing at its point of origin, had in fact already but vaguely sensed the essential, internal tension in the epoch of modernity. This tension may be described as the two-sided significance of science and technology for society, to which I shall assign the labels inventive science and transformative science:

1. By the term inventive science I mean the promise of 'the conquest of nature, the vision of an endless stream of new products and technologies to enhance the material conditions of life and human well-being.

2. By the term transformative science I mean the penetration of the 'ethos' of the modern scientific method throughout all of society and its institutions. This ethos includes the experimental method, with its emphasis on the objective demonstration of results, confirmed in a peer-review process; a thoroughly skeptical attitude to all received wisdom and traditional belief; the search for the 'laws of nature' existing independently of human thought and interests; and what we would now call an 'evidence-based' approach to the analysis of the causes of human misery, ignorance, and backwardness.[11]

The second is even more important than the first, in my view, but it has been virtually forgotten, shoved aside in the course of the triumphant march of the great triumvirate of science, technology, and industry. Nevertheless, it is the two forms of science together, and the tension between them, that make up the essential dialectic of modernity. To the extent to which the two sides exist in a creative tension, thus fostering historical progress, they counteract the twin obstacles to human development: first, lack of adequate material security, a necessary precondition for the full unfolding of human creativity, and second, a subjection to irrational forms of thought. The two do not exist in creative tension when the hyper-development of one side (inventive) is matched by the under-development of the other (transformative). In the latter case, which is the one that has persisted and intensified throughout the two preceding centuries (with some exceptions here and there), there is a growing risk that the enlarged technological powers will be put to the service of irrational social forces.

If the sentence immediately prior sounds a lot like the core theme found in Dialectic of Enlightenment, that is no accident. But the analysis of the underlying problematic is fundamentally different, not least in its concrete historical setting (modernity) and in its source, namely, modern science and its social context. It was the work of the eighteenth-century French Enlightenment-the 'real' Enlightenment, not the generic one constructed by Horkheimer and Adorno- that completed the development of Bacon's duality

To be sure, through the end of the eighteen-hundreds there were not all that many new 'products' emanating from scientific laboratories, although the foundations of invention were being laid down in the new sciences of chemistry and physics. During that period, however, the second part of the bargain, transformative science, triumphed over its opponents within European culture. This triumph is wonderfully summed up in the great posthumous work by the Marquis de Condorcet (1743-1794), Sketch for a Historical Picture of the Progress of the Human Mind, a work he wrote while in hiding from the agents of the Terror.[12] This text is the clearest statement of the idea that the new scientific methods are not only important for the truer understanding of nature. Rather, their highest importance lies 
in the fact that they can and should also be diffused throughout society, by means of universal education, and that social policy and social institutions will be rendered more humane and just as a result.

He envisioned a future in which 'the dissemination of enlightenment' would 'one day include in its scope the whole of the human race.'[13] The process called 'enlightenment' is founded on a way of thinking that instructs us 'to admit only proven truths, to separate these truths from whatever as yet remained doubtful and uncertain, and to ignore whatever is and always will be impossible to know.' The gradual extension of this method into the realm of 'moral science,' politics, and economics has enabled thinkers 'to make almost as sure progress in these sciences as they had in the natural sciences.' He continues:

This metaphysical method became virtually a universal instrument. Men learnt to use it in order to perfect the methods of the physical sciences, ... and it was extended to the examination of facts and to the rules of taste. Thus it was applied to all the various undertakings of the human understanding.... It is this new step in philosophy that has for ever imposed a barrier between mankind and the errors of its infancy, a barrier that should save it from relapsing into its former errors under the influence of new prejudices,...

Condorcet has an interesting reason for suggesting that advances in the natural sciences are the original foundation for a broader social enlightenment. He remarks that 'all errors in politics and morals are based on philosophical errors and these in turn are connected with scientific errors.' What he is saying is that there is a connection between our conceptions of natural processes, on the one hand, and our understanding of society and individual behaviour, on the other. Once the progress of the physical sciences' is launched, he claims, this 'inexorable progress cannot be contemplated by men of enlightenment without their wishing to make the other sciences follow the same path. It offers them at every step a model to emulate ....' This theme is nicely summed up in the following sentence: 'Just as the mathematical and physical sciences tend to improve the arts that we use to satisfy our simplest needs, is it not also part of the necessary order of nature that the moral and political sciences should exercise a similar influence upon the motives that direct our feelings and our actions?'[14]

If there is one core idea in Condorcet's conception, it is surely this: The 'progress of the sciences' that defines the enlightenment project is a double-sided phenomenon. It encompasses both the physical and the moral sciences or, using my terminology, the combination of inventive and transformative science, or technology and ethos. It is a process with a built-in mechanism ensuring its indefinite continuation: 'The progress of the sciences ensures the progress of the art of education which in turn advances that of the sciences.'[15] The inner unity between these two dimensions is something which Condorcet seems to have taken for granted. He saw the two sides as arising in quick succession over the course of the seventeenth century and flourishing together throughout the eighteenth. In short, a more sophisticated chemistry and physics, on the one hand, and enlightened social behaviour, on the other, were two sides of the same coin. That this is an inner unity, and not just a coincidence, is shown by Condorcet's emphasis on the great advances made possible by the invention of the calculus: It is not only a methodological pillar of the new natural sciences, but also of such innovations in social welfare as insurance and pension programs, which require the use of probabilistic analysis in order to function well.

Condorcet's Sketch is the most incisive, insightful, and comprehensive presentation of the underlying unity of enlightenment thought ever written by one of the key participants of the era. (It is a far better guide in this respect than is Kant's famous essay, What is Enlightenment?) But to the best of my knowledge there is no mention at all of Condorcet in Dialectic of Enlightenment. Thus critical theory never came to terms with the internal dialectic of the modern enlightenment_ nor did critical theory take a close look at the indispensable role played by the 'new sciences of nature' in it.

Horkheimer said in 1946, but only in an internal memorandum at the Institute for Social Research, that 'the rescue of the Enlightenment is our concern.'[16] If this is so (and it is believable), they chose a very odd way of going about it. For how could one not fully recognize, for example, the force and range in Condorcet's account of the struggle waged by enlightenment thought against regressive and oppressive forms of law and social custom? Yet it is in critical theory's failure to acknowledge the true significance of what the modern sciences of nature contributed in this regard that is one of its worst failings. Condorcet's profound insight, that 'scientific errors' supply one of the strongest supports for the errors in thinking that prop up oppressive social relations, was entirely overlooked.

Perhaps the worst failing of all is critical theory's failure to engage the specific content of what has been achieved in the modern sciences of nature, and its permanent value in the human understanding of the world in which we live. How can there be, in what styles itself as a critique, no mention of any actual achievement? How is it possible that can there be not even a passing acknowledgement of the scope and profundity of the collective intellectual labour over 
time that is represented, say, in Einstein's equations of special and general relativity, in molecular chemistry, or in the theory of evolution by natural selection? It is hard to excuse such a level of systematic oversight and condescension. How could these insights not be regarded as contributions to 'objective reason,' and instead be relegated implicitly to the sphere of subjective reason's 'interest in self-preservation'?

As Vogel has said, 'dialectic of enlightenment' ends in a cul-de-sac. But that is exclusively the theory's own problem. One cannot transcribe the theory's own radical shortcomings onto the historical reality it so poorly characterized.

\section{Scientific Mastery Over 'Internal Nature'}

Before discussing further where the tension between the two forms of science stands at present, I would like to explain the sense in which the project for the domination of nature is nearing completion. The four-hundred year trajectory of the new sciences was launched with studies on the forces and materials that make up the external environment-metals, minerals, energy, and organic compounds. Chemistry was the lead science; by the late eighteenth century its industrial applications were already established, and by the mid-nineteenth century products made using synthetic compounds, for example dyes, were pouring from the factories. Then it was the turn of physics, which dominated the late nineteenth century and the first half of the twentieth; the signature of its mastery is in the discovery and use of atomic energy.

The relatively slower progress in biology and genetics accelerated during its revolutionary period in the second half of the twentieth century: Molecular biology discovered that the book of life is written in the simple four-letter chemistry of the DNA molecule, and with that came the astonishing news that all living things that have ever existed on earth, plant and animal alike, share the same protein chemistry. Thus science's long trajectory now circles back and veers inward, exhibiting the human organism as a natural entity whose evolutionary origins and physiological makeup place it within the class of placental mammals. The genetic endowment of Homo sapiens_-including the genes that direct the construction of its brain - is so closely aligned with those of its nearest natural relatives, the bonobos and chimpanzees, that some molecular biologists regard all three species as being members of the genus Homo.[17]

We have had in hand, since 2003, the complete readout of the human genome, a sequence (akin to a barcode) of three billion chemical base-pairs, and the search for all of the 20-25,000 genes contained therein is on. The potential benefits of this knowledge are vast indeed. Just consider genetic disorders, the source of inherited diseases, which are basically mistakes in the sequence. Consider the disease known as Leigh Syndrome French Canadian Variant, a devastating childhood condition giving rise to multiple and severe physical and mental illnesses before death intervenes at age five or six. It results from a very small set of sequence errors within a single gene located on chromosome 2, and we now know exactly where and what those errors are.[18] We already have the ability to search for some of these kinds of single-gene errors in human embryos, including those that cause cystic fibrosis, Huntington's chorea, and some cancers - the procedure is called preimplantation genetic diagnostics-and parents can choose to discard the embryos that exhibit the defective gene sequences.[19]

But some day we will be able to repair those errors, too. And then it's a short step to gene enhancement, the construction of 'improved' versions of normal, healthy individuals. Many geneticists will tell you that it's 'impossible' or 'very difficult' to do such things, and that there are serious risks involved. That doesn't stop athletes from trying to get their hands on unproven technologies right now. My advice is, don't bet on the idea that gene enhancement technologies will never be realized. A safer bet would be to start preparing for the time when such technologies are available, and to expect that there will be a strong demand for them.[20] That is the advice given by an American neurologist, Anjan Chatterjee, in 2004. Chatterjee coined the term 'cosmetic neurology' as a deliberate reference to cosmetic surgery; he maintains that scientists and doctors will be unable to resist the demands from parents for 'souped-up' brains for their children.[21] Because in the entire range of human technologies, the ability to manipulate the brain will be seen as the greatest prize of all.

Using the working assumption that the brain gives rise to the mind, we are in the process of discoveringthrough the techniques known as neuroimaging-how the mind works, in other words, what brain functions are correlated with what mental outputs — thoughts, images, behaviors, emotions, reasoning, memory, and so forth.[22] All of these outputs are correlated with the 'firing' of specific neurons across synapses, in a process of electrical signaling among various regions of the brain. In turn, this neuronal activity is made possible by doses of chemicals 
known as neurotransmitters (serotonin, dopamine, norepinephrine, and others); and to a great extent, these chemical cascades are controlled by the on-off switching of the genes in our DNA and by levels of various hormones.

Once we know how brains work, we can manipulate them, of course: For example, the manipulation of serotonin levels in the brain, designed as a treatment for clinical depression, is achieved through administering a class of drugs known as SSRIs (selective serotonin reuptake inhibitors), the most famous of which is Prozac. But you don't have to wait for a doctor's prescription: College students today are taking a wide variety of 'memory-booster' drugs available over the Internet, especially around exam time.[23] And there's a lot more coming.

Domination of nature can be said to mean the effort to understand how all natural processes function, in terms of physical, chemical, and biological interactions, so that we can first replicate those processes and then intervene in them to produce specific outcomes that we desire. This long historical trajectory, which begins with the external world (environment), ends at the neurological tissue inside our heads, where our most intimate thoughts and feelings are generated. Once we have a good handle on all these functions, and how they are ultimately controlled by genes, we will be asked: 'What would you like us to do 'in there'? And, while we're at it, should we modify your genes as well, so that your children can inherit the nice new features and accessories we'll be adding?'

Along the way to the present, critical theory maintained, Enlightenment destroyed the possibility of 'objective' value-frameworks, so what remains is simply consumer preference. If your neighbor's children are competing with yours for limited places in the best schools, and the others have been endowed with souped-up brains, how long will you hold out? (Since this is a zero-sum game, it will be necessary for the schools to keep raising the bar, forcing parents to respond by upping the ante when they visit their genetic-engineering counselors.)

\section{The 'Task' That is Posited for Historical Actors}

In one of his finest aphorisms, from One-Way Street, Walter Benjamin remarks that the essential unfulfilled task for modern society is achieving 'mastery over the mastery of nature.' The thought remains as true today as when it was first penned in 1928.

The analysis presented here proposes that domination of nature has a specific meaning, considered as a key historical feature of the modern period: namely, the project of the modern natural sciences to achieve a complete technological mastery over natural processes. This is normally how this project is understood, but it is a radically deficient understanding, because it ignores the original unity of the two opposing, but complementary, moments within it. By means of a greatly enlarged technological mastery, humans have achieved powers and capacities of staggering proportions - such as capacities to transform the environment at will, and to dispose over the future development of all living things. But as originally conceived in enlightenment thought, this would be matched by another kind of mastery, namely, self-mastery: to figure out how to control the irrational impulses of human nature, by comprehending (through science) the sources of those impulses and by extending the domain of reason in social relations. The most succinct definition for this program was given by Freud: 'Where id was, there ego shall be.'

To date the program of balanced development has failed. We face a situation is which there is an escalating hyper-development of one side, named inventive science, matched by a persistent underdevelopment of the other, named transformative science. The sudden revival of religious militancy, both in the United States and in the Islamic world, is an ominous sign: The ancient dichotomy of good versus evil, the pleas sent to vengeful deities for the unleashing of every kind of horror on the 'other', the longing for the End Times-bathing the entire earth in blood and destruction - to commence: These deranged visions now swirl around the installations where stores of radioactive substances, nerve gases and other chemical weapons, and genetically-engineered plague pathogens sit quietly, waiting to be called into active service.[24]

The radical imbalance between inventive and transformative science puts modern society at increasing risk of having its powerful technologies thrown into the all-or-nothing 'final battle' named for the northern Israel town of Armageddon. And there is little prospect of even slowing down the pace of invention so that attempts might be made to steer a different course.

\section{| Postscript: Philosophy of History and The Need for Utopia}

For Hegel human history is the development through discrete stages of the idea of freedom. Historical 
development is driven, within discrete epochs, by a process of internal tension within a system of ideas that becomes dominant over time.

Progress-conceived of as the progressive deepening of the idea of freedom-is a circle: When an epoch of historical development starts drawing to a close, and nears 'fulfillment,' the human actors arrive back where they started—but not at the same place, to be sure. Rather, this 'back to the beginning' means that we are forced to confront, squarely and explicitly, a tension or contradiction that has been present in the entire period of development, and to resolve it. Until this is done we cannot move further forward, and unless it is done, we face regressive forces that threaten to undermine the positive achievements of the entire epoch.

Hegel used a famous metaphor - 'the Owl of Minerva takes flight at dusk' - to convey the idea that our insight into the essence of any historical epoch only occurs when it is drawing to a close, when the internal tension that lies at its core presents itself to historical actors explicitly—clearly and unequivocally—as an inescapable task to be addressed. I believe we have arrived at this point in the epoch called modernity.

It is the responsibility of critique to name correctly the nature of the stage of historical development that must be confronted and transcended (aufhebt). It is the calling of the imaginative faculty to suggest how the work of transcendence might actually be carried out. In its classical period, especially in the writings of Horkheimer and Marcuse, critical theory was suffused with the idea of utopia, the imagining of a better place.[25]

What works of utopian fiction try to do, among other things, is to identify some possible agents for the process of historical transformation that, according to the dialectical analysis, must be carried out.[26] Hera, or Empathy: A Work of Utopian Fiction is the first of three volumes in which I have made my own attempt to go down this road. [27] The presupposition for these works is the Hegelian philosophy of history just mentioned: Modern science in its essential duality (inventive and transformative) is the historical development that defines the epoch in which we live most concretely. The internal tension in that duality is reaching a critical point in the contemporary period. Whereas inventive science turns out ever more powerful and dangerous technologies, for example nuclear weapons and genetic engineering, the transformative moment appears to be stalled: Condorcet's vision has been replaced by the apocalyptic fantasies of total destruction and the 'end times' for humanity. Therefore, confronting and overcoming that tension is an inescapable task for present and future generations.

In earlier centuries during the modern period, especially the nineteenth, the critique of existing society was usually accompanied by some form of utopian vision, indicating in outline what path history might take after the deficiencies in social organization, identified by the critique, had been overcome. That way of thinking had atrophied by the end of the nineteenth century. I think it needs to be revived.

\section{Appendix}

\section{Further Remarks on Inventive and Transformative Science}

Hegel's dialectic cannot be represented by the mere opposition of two terms which are juxtaposed to each other in some form of 'tension' or perhaps 'contradiction.' Rather, each 'side' in this dynamic relationship is itself a unity of oppositional elements. There are actually four terms, instead of two, which must be specified. This level of complexity is in fact necessary in order for the full richness of the different possibilities to emerge during historical development.

The fourfold nature of dialectical opposition can be illustrated with an example from Marx, who was a very good Hegelian. From the familiar starting point,

\section{Proletariat $(\mathrm{A}) \longleftrightarrow$ Capitalism $(\mathrm{B})$,}

which are the primary terms of opposition, the expansion becomes:

Proletariat $(\mathrm{A} 1 \mathrm{~A} 2) \longleftrightarrow$ Capitalism $(\mathrm{B} 1 \mathrm{~B} 2)$

A1: the proletariat (working class) as one social class among others;

A2: the proletariat as a unique social class in all of history, the 'class that will end all classes'; [28] 
B1: capitalism as an arena in which the private appropriation of social wealth occurs, as it does in all forms of exploitative society;

B2: capitalism as a unique form of exploitative economy, one in which there is a massive expansion of productive resources, leading to qualitatively-enhanced opportunities for human progress.

As is well known, Marx assigned to the proletariat the decisive role of agent of change. To the extent to which the proletariat was unable to resolve its own set of inner contradictions (due to the weight of reification, or whatever), it would not be able to overcome the inner contradictions besetting the system of capital. The dialectical tension portrayed in this conception did indeed collapse, and in my view it cannot be revived (the moment has passed); thus it can no longer be considered to represent the driving force of historical change in the modern era.

By analogy, to represent the underlying dynamic of the project for the domination of nature in the terms suggested above, i.e., as embracing both inventive and transformative science, its structure can be portrayed in a similar fashion:

Inventive Science (A1 A2) $\longleftrightarrow$ Transformative Science (B1 B2)

A1: the pure understanding (discovery) of matter-energy transformation and the 'laws of nature, which have a universal character: knowledge for its own sake;

A2: the secular power and immense wealth which ownership and control of the technologies derived from modern science bestow on certain social classes, individuals, nations, and imperial powers;

B1: the diffusion of an enlightened, 'evidence-based' model of analysis into institutions, welfare policies, laws, universal education, moral theory, somatic and psychiatric medical therapies, penal systems, and behavioral control strategies; [29]

B2: the new potentialities for the control of human behavior, through the scientific description of the brain and, ultimately, an arbitrary disposition over genomes and genetic inheritances.

At least some of the consequences that flow from the development, over time, of these four dimensions are obvious. The project as a whole raises the stakes enormously in the game that humans are now playing, both with external nature (the environment and other living species) and with its own nature. Put in the language of risk, both the 'upside' and the 'downside' prospects are magnified enormously, compared to all earlier epochs.

\section{Endnotes}

\section{Dialectic of Enlightenment p. 20.}

2. Eclipse of Reason, p. 5. 'Subjective reason' is also called 'instrumental' and 'formalized' reason. See also his later work, Critique of Instrumental Reason (1967). So far as I know, Horkheimer never acknowledged or discussed the apparent similarity between his two forms of reason and Max Weber's earlier distinction between instrumental rationality and value rationality, developed in his Economy and Society (1914) - although he cites Weber on many other points.

3. Dialectic of Enlightenment, pp. 30-31.

4. Steven Vogel suggests that 'the project of enlightenment aims above all at the domination of nature' (Against Nature, p. 52, author's italics). Based on the quotations cited in the text, one could just as well reverse this proposition. I think that one is not the product of the other, but rather another name for the same phenomenon.

5. Max Horkheimer, Dawn and Decline, p. 237; the passage dates from the period 1966-1969.

6. The argument that Horkheimer and Adorno's project terminates in a cul-de-sac has been made some time ago by Vogel, and I think he is right: Against Nature, pp. 67-8. The entire discussion in his chapter 3 is a model of clarity and incisiveness.

7. To be sure the plausibility of this statement depends upon how one defines 'control.' Somewhere between 10,000 and 5,000 BCE settled communities were becoming common. 'Ötzi the Iceman,' discovered in a melting glacier in southern Austria in 1991, and thought to be 5,300 years old, may be regarded as a typical human of his time. He had a beautiful copper axe, a longbow and bone-tipped arrows, leather clothing and 
a woven grass cloak, finely-crafted footwear of complex design, a knife, pouch, flint, and a few other items; he was carrying medicinal herbs and his stomach contents included einkorn, an early species of cultivated wheat. We can assume he had a thatched hut back home. A few thousand years later, there are technologies involving massed labour, such as irrigated fields, buildings using massive stone, domesticated animals, arts and crafts (metalworking, pottery, fine cloth, etc.), ships, etc. But, right down to the beginnings of the modern era, in my view none of this constitutes 'control over nature' in any meaningful sense of the word 'control.'

8. This is the element of 'cunning' featured in the famous discussion of Odysseus in Dialectic of Enlightenment (see Vogel, pp. 54-5). But Horkheimer and Adorno can only link The Odyssey with Francis Bacon's The New Organon on the basis of their own purely formalistic conception of instrumental reason-an ironic situation, to be sure, for the theorists who criticize enlightenment as an expression of formalized reason. For nothing at all actually links the story of Odysseus and the Sirens with what Bacon and his followers were attempting to do and indeed, what they actually achieved. Guided and inspired by Bacon, later generations created a historical novelty of immense and fateful significance: the methodical investigation of natural processes conceived of as the product of an open-ended social and institutional agenda, spanning entire generations over what is now a period of nearly four hundred years. And it is simply absurd to write off what they created thereby, the by now immense structure of the modern sciences of nature, which is surely, among other things, an extraordinary product of the creative human imagination, as nothing more the latest expression of a radically deficient instrumentalist approach to life (there is further commentary on this point later on in the text).

9. The 'reconciliation' of modern science and ancient religion remains an active project right down to the present, and both theologians and many working scientists are engaged in a dialogue about it.

10. See my The Domination of Nature, chapter 3.

11. See the Appendix for a formal analysis of the opposition between transformative and inventive science, represented in terms of the Hegelian dialectic.

12. Condorcet, a member of the aristocracy, supported the French Revolution, but he was arrested during the Terror and committed suicide while awaiting execution. See The Domination of Nature, pp. 77-9.

13. Sketch for a Historical Picture of the Progress of the Human Mind, pp. 127ff.

14. Ibid., pp. 163-4, 192.

15. Ibid., p. 196.

16. Cited in the Editor's Afterword, Dialectic of
Enlightenment, p. 241.

17. Wildman et al. (2003).

18. Mootha et al. (2003). The disease affects 1 out of every 2,000 live births in the Sangueney-Lac St.-Jean region of Québec.

19. See Amy Harmon, 'Couples cull embryos to halt heritage of cancer,' The New York Times, 3 September 2006.

20. My personal view is that using genetic screening (and eventually gene repair) to eliminate the most serious inherited diseases is unproblematic, from an ethical standpoint, although careful reasoning is needed to determine 'where to draw the line' in terms of what type of condition is sufficiently debilitating to justify these procedures. I would proscribe gene enhancement completely. Such matters demand consideration at much greater length.

21. Chatterjee (2004).

22. Montreal researchers are using a group of elderly Carmelite nuns as research subjects in an attempt to pin down the locus of the so-called 'God spot' in the brainwhere the unio mystica, the mystical union of the person with God, is experienced: M. Beauregard and V. Paquette, 'Neural correlates of a mystical experience in Carmelite nuns.' For a good general discussion, see Illes and Racine (2005).

23. If you put 'memory enhancing drugs' into your Google search engine, Google will give you, on the sidebar, a nice selection of websites offering products to choose from, which can be ordered conveniently with a click of your mouse.

24. D. Rising, 'Terrorist exhorts nuclear experts to join jihad,' The Globe and Mail (Toronto), 29 September 2006, A9.

25. This theme is emphasized in the Introduction by Feenberg and Leiss to The Essential Marcuse (2007). To be sure, this was, as Russell Jacoby reminds us in Picture Imperfect, 'negative utopia,' that is, only the abstract idea of a future, better world.

26. An important theme which cannot be developed here is this: What is presupposed is that the content of the knowledge bestowed by the modern sciences-in particular, the biological sciences-must be engaged by social theorists. For example, the propositions that the species Homo sapiens, including its marvelous brain, is entirely a random result of natural evolution; that this species shares much of its genome with other mammals; that the human mind is entirely the 'product' of highly-evolved neurological structures: These truly revolutionary, evidence-based propositions must be considered to be important factors in the range of possibilities for social development that lie in the future. 
27. Book Two of the The Herasaga trilogy is entitled The Priesthood of Science and will appear in 2008.

28. For nostalgic reasons I must mention an article I published on this remarkable concept in 1974, 'Critical Theory and its Future.'
29. S. Blakeslee, 'Out-of-body experience? Your brain is to blame,' The New York Times, 3 October 2006, offers just one example of how the scientific understanding of the brain and mind provides an alternative explanation to what would otherwise be represented as a 'mystical' phenomenon.

\section{References}

Beauregard, M. and V. Paquette. Neural correlates of a mystical experience in Carmelite nuns. Neuroscience Letters, 405 (2006), 186-190.

Chatterjee, A. Cosmetic Neurology: The controversy over enhancing movement, mentation, and mood. Neurology 63 (2004), 968-74.

Condorcet, Marquis de. Sketch for a Historical Picture of the Progress of the Human Mind [1795]. Translated by J. Barraclough. New York: Noonday Press, 1955.

Horkheimer, Max. Eclipse of Reason. New York: Columbia University Press, 1947.

------- Critique of Instrumental Reason. New York: Seabury Press, 1974.

-..--.- Dawn and Decline: Notes 1926-1931 and 1950-1969. Translated by Michael Shaw. New York: The Seabury Press, 1978.

-..----and T. W. Adorno. Dialectic of Enlightenment [1947, 1969]. Edited by Gunzelin Schmid Noerr and translated by Edmund Jephcott. Stanford, CA: Stanford University Press, 2002.

Illes, July and Eric Racine. Imaging or Imagined? A neuroethics challenge informed by genetics. American Journal of Bioethics 5 (2005), 5-18.

Jacoby, Russell. Picture Imperfect. Columbia University Press, 2005.
Leiss, William. Critical Theory and its Future. Political Theory, 2 (1974), 330-49: http://www.leiss.ca/index. php?option $=$ com_content $\&$ task $=$ view $\&$ id $=90 \&$ Itemid $=48$

-------The Domination of Nature (1972). Republished with new Preface, Montreal: McGill-Queen's University Press, 1994.

-.----- Hera, or Empathy: A Work of Utopian Fiction. Ottawa, Ontario, 2006: www.herasaga.com .

Marcuse, Herbert. The Essential Marcuse. Edited by Andrew Feenberg and William Leiss. Boston, MA: Beacon Press, 2007.

Mootha, V. K. et al. Identification of a gene causing human cytochrome c oxidase deficiency by integrative genomics. Proceedings of the National Academy of Sciences, 100 (2003), 605-610.

Vogel, Steven. Against Nature: The Concept of Nature in Critical Theory. Albany, NY: State University of New York Press, 1996.

Weber, Max. Economy and Society, eds. G. Roth and C. Wittich. 2 vols. University of California Press, 1978.

Wildman, Derek et al. Implications of natural selection in shaping 99.4\% non-synonymous DNA identity between humans and chimpanzees: Enlarging genus Homo. Proceedings of the National Academy of Sciences, 100 (2003), 7181-8. 